\title{
Effect of Probiotics Supplementation on the Performance of Lactating Crossbred Cows
}

\author{
V. M. Vibhute, R.R. Shelke*, S.D. Chavan, S.P. Nage \\ Dr. Punjabrao Deshmukh Krishi Vishwavidyalaya (Dr.PDKV), \\ Akola, 444104, Maharashtra, India \\ * Corresponding author email:rrspkv@gmail.com
}

Received: 17-05-2011, Accepted: 13-06-2011, Published Online: 23-10-2011

doi: $10.5455 /$ vetworld.2011.557-561

\begin{abstract}
Sixteen multifarious cows were selected on the basis of average daily milk yield and stage of lactation; they were divided into four groups (four cows in each group) with parity within each group. These cows were fed $10 \mathrm{gm}, 15 \mathrm{gm}$ and $20 \mathrm{gm}$ probiotics just before evening milk. The multi-strain probiotic used were containing four strains consist of bacteria and fungi namely Lactobacillus acidophilus, Saccharomyces cerevisiae, Saccharomyces boulardii and Propionibacterium frendenreichii. It was found that, the use of probiotics proved to be effective in increasing milk production of lactating cows. Milk fat, milk protein and SNF content tended to be higher in cows supplemented with probiotics preparations. The appropriate level of $20 \mathrm{gm}$ probiotic per day per animal was found effective. The economic advantage of probiotics depends on its relative prices and on the levels of milk production of the cows.

Keywords: Probiotic ,Aspergillus oryzae (AO), Saccharomyces cerevisiae (SC), Yeast Culture (YC),Dry matter(DM), Crude Protein (CP), Crude Fiber (CF), Ether extract (EE), Nitrogen free extract (NFE). Solid-Not-Fat (SNF),Total Mixed Ration (TMR).
\end{abstract}

\section{Introduction}

The term probiotic derived from the Greek word meaning 'for life' and first introduced in 1953 by Kollath (Hamilton-Miller et al. 2003). Ray Fuller (1989) defined probiotic as "A live microbial feed supplement, which beneficially affects the host animal by improving its intestinal microbial balance". According to currently adopted definition by FAO and WHO, probiotics are; "live microorganism which when administered in adequate amount confers a health benefit on the host".

The most commonly used organisms in probiotic preparations are the lactic acid bacteria (Lactobacillus, Streptococci, bifidobacteria).These are found in large numbers in the gut of healthy animals and do not appear to affect them adversely. Fungal probiotics may produce their beneficial effects in three ways by stimulation of indigenous fungi (Huber, 1990), by increasing the number of cellulolytic bacteria in the rumen (Dawson, 1990), by improved rumen metabolism resulting from decreased concentration of lactic acid which, in turn reduces rumen $\mathrm{pH}$. Anaerobic fungi yeast (Saccharomyces cerevisiae, Saccharomyces boulardii) and filamentous fungi ( Aspergillus oryzae) being used for probiotic preparations. Yeast, because of their ability to ferment sugar is named saccharomyces (sugar fungi). In a well aerated sugar, the yeast grows and undergoes normal aerobic respiration producing carbon dioxide and water. The different types of probiotics have different potential for fermentation or metabolism by the intestinal micro flora. In livestock production, probiotics can be employed to control pathogenic bacteria in the intestine tract, reduce methane emissions, enhance growth performance, immune regulation etc. The probiotics preparation may consist of single strain or can also have a mixture of different strains, which can be numbered up to nine. The probiotics can be presented in various ways such as capsules, paste, powder or granules.

Iwanska et al. (2000) studied the effect of biologically active compounds on milk yield and composition. Data were obtained on thirty multiparous Polish Black and White cows indicate that fat corrected milk yield, milk fat yield, milk protein yield, casein yield, lactose percentage, total solid, solid-not-fat and somatic cell count were significantly higher. Meeske et al. (2002) found that addition of 
lactic acid bacterial inoculants to maize at ensiling improved the palatability, intake and the aerobic stability of maize silage compared to control. Sablik (2002) conducted two studies to analyze the effect of Yea-Sacc ${ }^{1026}$ probiotic (composed of Saacromyces cerevisiae $)$ and Bioplex mineral mixture $(\mathrm{Cu}, \mathrm{Mn}, \mathrm{Zn}$, and $\mathrm{Cr}$ ) on milk yield, composition, reproductive performance, and level of biochemical indices $(\mathrm{Ca}, \mathrm{P}$, $\mathrm{K}, \mathrm{Mg}, \mathrm{Cu}, \mathrm{Fe}, \mathrm{Zn}$ and $\mathrm{Se}$ ) in dairy cows. It was observed that there was a significant increase in milk yield and FCM when $15 \mathrm{~g}$ of Yea-Sacc ${ }^{1026}$ was given to the cows in both experiments. There was also significant increase in milk fat and protein yield in both experiments.

Yasuda and Fukata (2004) demonstrated effect of mixed feed containing dextran on total 37 Holstein Friesian dairy cows. Cows were randomly divided into two groups; Group A - control, group B - fed with 30 $\mathrm{g} / \mathrm{head} / \mathrm{day}$ of mixed feed containing supplemental dextran for one year. They observed that milk yield of group B were greater than the yield of group A. Also after the supplementation, concentrations and total amounts of fat, protein and SNF significantly increased more in group B than group A.

Alshaikh et al. (2007) indicated that cows consuming those diets supplemented with yeast culture tented to decrease their dry matter intake and to increase their milk yield. Cows fed with $\mathrm{YC}_{2}$ supplemented diets produced more milk and 4\% FCM than those fed either the $\mathrm{YC}_{1}$ supplemented or the control diet. Kudrna et al. (2007) noted that yeast supplementation significantly improved the milk yield despite reducing the dry matter intake. Chandrasekharaiah et al. (2007) concluded that characteristic, sources, production of prebiotics as well as the influence of prebiotics on animal production have potential to increase milk yield and composition under Indian condition. Wholt et al. (1998) revealed that numerical responses in DM intake and milk yield were greater for cows fed 20 $\mathrm{g} /$ day of yeast than for $10 \mathrm{~g} /$ day of yeast. Kim et al. (2001) observed that total income per milk yield was highly improved by the supplementation of $0.5 \%$ probitics (Economix).

The present investigation was conducted with major objective to study the effect of probiotics on milk production, to determine the effect of probiotics on milk composition of lactating cows and to estimate the cost of probiotics feeding.

\section{Materials and Methods}

The present investigation was undertaken at
Livestock Instructional Farm, Department of Animal Husbandry and Dairying, Dr.P.D.K.V. Akola during the year 2009-10.

Selection of Animals - Sixteen multifarious cows in their early to mid lactation stage (lactation number 2 to 6 ) and having an average daily two week pretrial milk yield of 2-3 liters were selected and divided into four groups (four animals in each group) in such a way that the order of lactation and average milk yield of four groups were more or less similar. The present experiment was conducted by using Randomized Block Design (RBD) with four treatments $\mathrm{T}_{1}$-Without Probiotic (control), $\mathrm{T}_{2}$ - Multi-strain Probiotic $10 \mathrm{~g}$. , $\mathrm{T}_{3}$ - Multi-strain Probiotic 15 g. and $\mathrm{T}_{4}$ - Multi-strain Probiotic $20 \mathrm{~g}$.

Ingredients and formulation of diets - The total mixed ration consisted of green berseem (Trifolium alexandrium), maize (Zea mays), Jowar straw, and 0.5 $\mathrm{kg}$ concentrate mixture for every $1 \mathrm{~kg}$ milk produced/cow/day. Also $3 \mathrm{~kg}$ silage /cow/day was given.The concentrate mixture used for this study was "Sugras " manufactured by "M/s Maharashtra Agro Industries Development Corporation Ltd. In addition, $30 \mathrm{~g}$ sodium bicarbonate as buffer was given to all the animals.

The multi-strain probiotic used were containing four strains consist of bacteria and fungi namely Lactobacillus acidophilus, Saccharomyces cerevisiae, Saccharomyces boulardii and Propionibacterium frendenreichii. Multi-strain probiotic was supplied by Wockhardt Co. Mumbai namely Biovet-YC Gold.

Four complete diets were formulated using Sugras (concentrates) and forage maize, berseem with concentrate: forage ratio 60:40 on a dry matter basis. The total mixed ration fed was the same for all four groups. Remaining three groups consisted multi-strain probiotic $10 \mathrm{~g}\left(\mathrm{~T}_{2}\right), 15 \mathrm{~g}\left(\mathrm{~T}_{3}\right), 20 \mathrm{~g}\left(\mathrm{~T}_{4}\right)$.

Feeding of experimental diets: The experimental animals were fed with concentrate mixture just before evening milk when animals are brought to the parlor for milking. The concentrate mixture was fed at the rate of $0.5 \mathrm{~kg}$ for every $\mathrm{kg}$ milk produced /day/animal. For two weeks preliminary trial period only total mixed ration were fed. After two weeks preliminary period probiotics were substituted with total mixed ration.

\section{Recording of observations}

Milk production: Milk production was recorded daily both in the morning and evening for whole experimental period.

Milk composition: Milk samples were drawn for analysis from morning and evening milking once in 
every week throughout the experimental period. Fat content of milk was determined by Gerbers method as described in IS-1224 Part I (1977). Protein per cent was determined as per ISI Handbook of Food analysis SP:18 (Part-IX):1981. SNF per cent was determined as per IS:1479(Part-I): 1960 .

Statistical Analysis: The data was analyzed by statistical method Randomized Block Design (RBD).

\section{Results and Discussion}

Effect of Probiotics supplementation on milk production: Table 1 shows mean values of weekly average milk production for the pretrial period of two weeks, trial period of six weeks and post trial period of two weeks for treatments $\mathrm{T}_{1}, \mathrm{~T}_{2}, \mathrm{~T}_{3}$, and $\mathrm{T}_{4}$.

Table-1. Effect of probiotics supplementation on milk production

\begin{tabular}{llllllll}
\hline Trials & Week & T1 & T2 & T3 & T4 & SE (m) & CD \\
\hline Pre -trial & Mean of & 32.81 & 34.14 & 38.11 & 38.10 & 0.272 & 0.616 \\
Trial & $\begin{array}{l}\text { Mean of } \\
\text { The }\end{array}$ & 35.85 & 38.79 & 39.51 & 43.51 & 0.030 & 0.068 \\
$\begin{array}{l}\text { Post Trial } \\
\text { (Residual }\end{array}$ & $\begin{array}{l}\text { Mean of } \\
\text { 9 \& 10 }\end{array}$ & 35.58 & 41.25 & 43.33 & 47.46 & 0.026 & 0.059 \\
Effect) & & & & & & \\
\hline
\end{tabular}

It is observed from above table that average milk production of pre trial period (two weeks) was 32.81, $34.14,38.11$ and $38.1 \mathrm{Kg}$ for treatments $\mathrm{T}_{1}, \mathrm{~T}_{2}, \mathrm{~T}_{3}$, and $\mathrm{T}_{4}$ respectively. This means that there were not significant differences between all treatments before starting experiment. However, after starting feeding probiotics from third week changes in milk production was observed gradually. It is observed that milk production of $\mathrm{T}_{1}, \mathrm{~T}_{2}, \mathrm{~T}_{3}$ and $\mathrm{T}_{4}$ was $35.85,38.79,39.51$ and $43.51 \mathrm{~kg}$ respectively after treatment period of six weeks. If these values compared with pretrial period it indicates that there is gradually increase in milk production among treatments starting from $\mathrm{T}_{2}$ to $\mathrm{T}_{4}$.

Milk production of treatments $T_{4}$ was significantly superior over $\mathrm{T}_{1}, \mathrm{~T}_{2}, \mathrm{~T}_{3}$ treatments respectively. Among treatments, $\mathrm{T}_{4}$ was significantly superior, treatments $T_{2}, T_{3}$ were moderately superior over $\mathrm{T}_{1}$ (control). But there was no marked difference between treatments $\mathrm{T}_{2}$ and $\mathrm{T}_{3}$. The responses in milk production improvements for the treatments supplied with probiotics were observed throughout the experimental period.

For the experimental trial period, animals in experimental group produced on an average 8, 10, $21.36 \%$ more milk/week compared to control group. It is in accordance with dietary supplementation of synbiotics 3-16\% more milk was reported by Yasuda et al. (2007).
Effect of probiotics supplementation on milk fat (\%): It is indicated from the table 2 that average fat per cent of pre trial period (two weeks) was 3.46, 3.68, 3.58 and $3.67 \%$ respectively. This means that there were not significant differences between all treatments before starting experiment. After completion of experimental period of eight weeks, the fat percent of $\mathrm{T}_{1}, \mathrm{~T}_{2}, \mathrm{~T}_{3}$ and $\mathrm{T}_{4}$ were $3.42,3.65,3.82$ and $4.15 \%$ respectively. This shows that treatment $\mathrm{T}_{4}$ was significantly superior over remaining treatments .Though there were no significant differences between treatments $T_{2}$ and $T_{3}$, both are moderately significant over $\mathrm{T}_{1}$. The effect of probiotics on fat per cent of treated cows was significant during experimental period. There were differences of $0.73,0.5,0.33$ and $0.17 \%$ in treatment $\mathrm{T}_{4}$ and $\mathrm{T}_{1}, \mathrm{~T}_{4}$ and $\mathrm{T}_{2}, \mathrm{~T}_{4}$ and $\mathrm{T}_{3}, \mathrm{~T}_{3}$ and $\mathrm{T}_{2}$ respectively. Above results are in agreement with the results of those reported by Yasuda and Fukata (2004) that the amount of total fat in milk of treated group was significantly higher than for control group.

Table-2. Effect of probiotics supplementation on chemical composition of milk. (\%)

\begin{tabular}{|c|c|c|c|c|c|c|c|}
\hline $\begin{array}{l}\begin{array}{l}\text { Trial } \\
\text { (Weeks) }\end{array} \\
\end{array}$ & Constituent & $\mathrm{T1}$ & $\mathrm{T2}$ & T3 & T4 & $S E(m)$ & $C D$ \\
\hline $\begin{array}{l}\text { Pre trial } \\
\text { (Mean values } \\
\text { of } 1 \& 2 \text { ) } \\
\text { Trial } \\
\text { (Mean values } \\
\text { of } 3 \text { to } 8 \text { ) } \\
\text { Post trial } \\
\text { (Mean values } \\
\text { of } 9 \& 10 \text { ) }\end{array}$ & $\begin{array}{l}\text { Fat } \\
\text { Protein } \\
\text { Solid not fat } \\
\text { Fat } \\
\text { Protein } \\
\text { Solid not fat } \\
\text { Fat } \\
\text { Protein } \\
\text { Solid not fat }\end{array}$ & $\begin{array}{l}3.46 \\
3.3 \\
8.81 \\
3.42 \\
3.31 \\
8.82 \\
3.37 \\
3.31 \\
8.82\end{array}$ & $\begin{array}{l}3.68 \\
3.3 \\
8.81 \\
3.65 \\
3.31 \\
8.83 \\
3.74 \\
3.34 \\
8.85\end{array}$ & $\begin{array}{l}3.58 \\
3.3 \\
8.82 \\
3.82 \\
3.33 \\
8.83 \\
3.86 \\
3.34 \\
8.855\end{array}$ & $\begin{array}{l}3.67 \\
3.33 \\
8.83 \\
4.15 \\
3.35 \\
8.85 \\
4.31 \\
3.37 \\
8.88\end{array}$ & $\begin{array}{l}0.030 \\
0.026 \\
0.002 \\
0.026 \\
0.002 \\
0.002 \\
0.026 \\
0.003 \\
0.004\end{array}$ & $\begin{array}{l}0.068 \\
0.059 \\
0.005 \\
0.059 \\
0.005 \\
0.005 \\
0.059 \\
0.007 \\
0.008\end{array}$ \\
\hline
\end{tabular}

Effect of probiotics supplementation on milk protein $(\%)$ : It is revealed from table 2 that average protein per cent for pre trial period (two weeks) was 3.3, 3.3, 3.3 and 3.33 respectively. This means that there were not significant differences between all four treatments while starting actual experiment. Mean protein per cent of eight weeks of feeding for treatments $\mathrm{T}_{1}, \mathrm{~T}_{2}, \mathrm{~T}_{3}$ and $\mathrm{T}_{4}$ after completion of eight weeks trial period were $3.31,3.31,3.33$ and $3.35 \%$ respectively. This shows that there were differences of $0.04,0.04,0.02$ and 0.02 between treatments $\mathrm{T}_{4}$ and $\mathrm{T}_{1}$, $\mathrm{T}_{4}$ and $\mathrm{T}_{2}, \mathrm{~T}_{4}$ and $\mathrm{T}_{3}, \mathrm{~T}_{3}$ and $\mathrm{T}_{2}$ respectively. It reveals from this difference that treatment $T_{4}$ was significantly superior over treatments $\mathrm{T}_{1}, \mathrm{~T}_{2}, \mathrm{~T}_{3}$. While, there was no any marked differences in treatments $T_{3}$ and $T_{2}$, but both have higher values than $\mathrm{T}_{1}$.

These results are in accordance with Singh and Kumar (1996), they showed that addition of probiotic containing (Yea-Sacc ${ }^{1026}$ ) increases milk protein content by $11.90,21.43$, and $21.43 \%$ for 5,10 , and 15 $\mathrm{g} \mathrm{Yea-Sacc}{ }^{1026} /$ day/animal. 
Effect of probiotics supplementation on SolidsNot-Fat content: Above table reveals that average solids-not-fat per cent for pre trial period (two weeks) was $8.81,8.81,8.82$ and $8.83 \%$ for treatments $\mathrm{T}_{1}, \mathrm{~T}_{2}$, $\mathrm{T}_{3}$ and $\mathrm{T}_{4}$, respectively. It means that there were not significant differences between all four treatments while starting actual experiment. Mean solids-not-fat per cent of eight weeks of feeding for treatments $\mathrm{T}_{1}, \mathrm{~T}_{2}$, $\mathrm{T}_{3}$ and $\mathrm{T}_{4}$ were $8.82,8.83,8.83$ and $8.85 \%$, respectively. This reveals that there was average higher solids-notfat per cent for $\mathrm{T}_{4}$ than other treatments groups viz. $\mathrm{T}_{1}$, $\mathrm{T}_{2}$ and $\mathrm{T}_{3}$. This shows that treatment $\mathrm{T}_{4}$ is slightly significant than treatment $\mathrm{T}_{1}, \mathrm{~T}_{2}$ and $\mathrm{T}_{3}$. The treatments $\mathrm{T}_{1}, \mathrm{~T}_{2}$ and $\mathrm{T}_{3}$ are at par with treatments $\mathrm{T}_{4}$ and there was no any marked difference between $\mathrm{T}_{1}, \mathrm{~T}_{2}$ and $\mathrm{T}_{3}$. These results are in agreement with Yasuda et al. (2007), they found that the amount of solids-not-fat in milk of treated group was significantly increased in comparison those of control group.

Cost of probiotics supplementation: During the six weeks period of probiotics feeding, cows were fed with roughages like maize, berseem, jowar straw and concentrate (sugras). In addition, all cows were grazed on pasture. Hence during calculation of feeding the probiotics, cost of roughages, concentrates were not included in order to avoid unnecessary calculations. Only probiotics product is taken into consideration. Cost of probiotics product is as follows.

Biovet YC Gold - 400 INR. By taking into consideration, this costs, economics of probiotics feeding are given in Table 3 .

Table-3. Cost of probiotics on supplementation

\begin{tabular}{lcccc}
\hline Particulars & T1 & T2 & T3 & T4 \\
\hline Milk production $(\mathrm{kg})$. & 35.85 & 38.79 & 39.51 & 43.51 \\
Probiotics used $(\mathrm{g}) /$ animal. & - & 10 & 15 & 20 \\
Total cost of probiotics /animal/day & $(\mathrm{INR})-$ & 4 & 6 & 8 \\
Cost/Kg milk production (INR) & - & 0.10 & 0.15 & 0.18 \\
\hline
\end{tabular}

As treatment $T_{1}$ had given only Total Mixed Ration without probiotics, cost of feeding probiotics is not calculated for it. However, for remaining treatments cost of feeding probiotics is given in table- 3 .

Treatment $\mathrm{T}_{4}$ required only $0.18 \mathrm{Rs}$. Per $\mathrm{kg}$ of milk produced as compared to Rs. 0.10 and 0.20 for treatments $\mathrm{T}_{3}$ and $\mathrm{T}_{2}$ respectively.From above analysis it is found that treatment $T_{4}$ containing $20 \mathrm{~g}$ probiotics was found most effective with cost required for per $\mathrm{kg}$ milk produced.

\section{Conclusion}

The use of probiotics proved to be effective in increasing milk production of lactating cows. Milk fat, milk protein and SNF content tended to be higher in cows supplemented with probiotics preparations. Gradual improvement was observed in overall milk composition with supplementation of probiotics. The effect of probiotics preparations started reflecting in milk production and milk composition even during the first week of supplementation and marked increase was noticed from fourth week onwards. The appropriate level of $20 \mathrm{gm}$ probiotic per day per animal was found effective. The economic advantage of probiotics depends on its relative prices and on the levels of milk production of the cows.

\section{Acknowledgement}

Authors are thankful to The Head, Dept. of Animal Husbandry and Dairying, Dr.PDKV, Akola, for providing necessary facilities.

\section{References}

1. Alshaikh, M. A.; M. Y. Alsiad.; S. N. Zahran.; H. H Mogawar.; T. A. Aulshowime. (2007). Effect of feeding yeast culture from different sources on the performance of lactating Holstein cows in Saudi Arabia. Asian-Australian J. ofAni.Sci.15 (3):352-356.

2. Chandrasekharaiah, M.; K. T. Sampath.; C. S. Prasad.; A. K Samanta.; A. P. Kolte. (2007). Prebiotics: the rumen modulator for enhancing the productivity of dairy animals. Indian Dairyman.59 (8):58-61.

3. Dawson, K. A.; K. E. Newman and J. A. Boling. (1990) Effect of supplement containing yeast and lactobacilli on roughage feed ruminal microbial activities. J. Anim. Sci. 68:3392-3398.

4. Fuller, R. (1989). Probiotics in man and animals. J. Appl. Bacteriol. 66:365-376.

5. Hamilton J. M. T. and Miller et al.. (2003). Probiotics and prebiotics in the elderly. Post Graduate Medical J. 80: 47 57.

6. Huber, J. T. (1990). The fungal and yeast culture story in lactating dairy cows. In Proc. South West Nutr. Manage. Conf., Tempe. AZ. 87-94.

7. Iwanska, S.; D. Strusinska.; A. Opalka. (2000). Effect of biologically active compounds on milk yield and composition. Roczniki Naukowe Zootechniki.6:46-50.

8. IS-1224, Part-I.(1977). Determination of fat by Gerbers method. Indian Standard Institute, Manak Bhavan. New Delhi.

9. IS -1479, Part II, (1961). Methods of test for dairy industry. Indian Standard Institute, Manak Bhavan, New Delhi.

10. Kim, J.H.; C.H. Kim.; Y.D. Ko. (2001). Effect of dietary supplementation of probiotics (Economix $\left.{ }^{\circledR}\right)$ on milk production and economic characteristics in lactating dairy cows. J.Ani.Sci.and Tech. 43(3):369-380.

11. Kudrna, V.; K. Polakova.; P. Lang.; J. Dolezal. (2007). The effect of different yeast strains on milk yield, fatty acid profile and physiological parameters in dairy cows. In $57^{\text {th }}$ Annual Meeting of the European Association for Animal Production, Antalya, Turkey.61 (1):29-33.

12. Meeske, R; G.D. Merwe,; J.F. Van Der Greyling.; C.W Craywagan. (2002). Effect of addition of a lactic acid bacterial inoculant to maize at ensiling on silage composition, silage intake, milk production and milk 
compositon. South African J. of Ani. Sci.32 (4):263-270.

13. Singh, S. and U. kumar,(1996). Effect of supplementation of yeast culture (Yea-Sacc ${ }^{1026}$ ) on milk yield and its composition of Murrah buffaloes. Indian J. Anim. Sci. 66:71-72.

14. SP:18, Part IX, (1981). Handbook of Food Analysis. Indian Standard Institute, Manak Bhavan, New Delhi.

15. Wholt, J. E.; A. D. Finkelstein and C. H. Chung. (1991)

Yeast Culture to improve intake, nutrient digestibility and performance in dairy cows during early lactation. $J$ Dairy Sci. 74: 1400 .

16. Yasuda, K., S.S. Hashikawa, Y. Tomita, S. Shibala and Tsuneo, (2007). A new syntiobic consisting of Lactobacillus casei subsp. Casei and Dextran improves milk production of Holstein Dairy cows. J. Vet. Med. Sci. 69(2):205.

17. Yasuda, K. and T. Fukata, (2004). Mixed feed containing dextran improves milk production of Holstein Frisian Dairy cows. J. Vet. Med. Sci. 66(10):1287-1288. 